\title{
PENGALURAN ATAU PEMPLOTAN DALAM KARYA SASTRA
}

\author{
Saleha Astri Rahaningmas ${ }^{1)}$, Nurysamsi Maulana Insani ${ }^{2)}$ \\ ${ }^{1,2)}$ Fakultas Sastra, Universitas Muslim Indonesia \\ Jalan Urip Sumoharjo KM 5, Makassar \\ yhuniastri@gmail.com ${ }^{1)}$, nurysamsimaulana11@gmail.com ${ }^{2)}$
}

\begin{abstract}
Abstrak: Alur adalah rangkaian peristiwa yang di jalin dengan seksama, yang mengerakkan jalan cerita melalui rumitan kearah klimks dan anti klimaks. Dengan kata lain, alur adalah jalinan peristiwa di dalam karya astara untuk mencapai efek tertentu dan pautan dapat diwujudkan oleh hubungan temporar (waktu) dan hubungan kausal (sebab akibat). Alur atau plot dapat dikatakan rangkaian peristiwa atau cerita yang dimulai dengan cerita pembukaan diakhiri dengan penutup cerita. Dalam rangkaian cerita tersebut, peristiwa atau cerita disusun seolah-olah sebagai kisah yang benar-benar hidup atau nyata dan suatu cerita fiksi dapat menarik pembaca bila pengarang mampu membawa atau menggiring pembaca untuk mengikuti alur cerita.
\end{abstract}

Kata kunci: pengaluran, karya sastra

\section{PENDAHULUAN}

Alur atau pemplotan merupakan unsur fiksi yang penting, bahkan tidak sedikit orang menganggap lebih penting dari unsur fiksi yang lain. Alur mengatur bagaimana tindakan-tindakan harus bertalian satu sama lain, bagaimana suatu peristiwa berhubungan dengan peristiwa lain, bagaimana tokoh di gambarkan dan berperan dalam peristiwa itu yang semuanya terikat dalam suatu kesatuan waktu. Alur merupakan tulang punggung suatu cerita, yang menuntun kita memahami keseluruhan cerita dengan segala sebab-akibat di dalamnya.

Penampilan peristiwa demi peristiwa yang hanya mendasarkan diri dari urutan waktu saja belum merupakan plot, agar menjadi suatu plot maka peristiwa-peristiwa tadi harus diolah dan disiasati secara kreatif. Sehingga hasil pengolahan dan penyiasatan itu sendiri merupakan sesuatu yang indah dan menarik, khususnya dalam kaitannya dengan karya fiksi yang bersangkutan secara keseluruhan. Sifat plot misterius dan intelektual menampilkan kejadian-kejadian yang mengandung konflik yang mampu menarik atau bahkan mencekam pembaca. Sifat plot tersebut tampaknya tak berbeda kaitannya dengan pengertian suspense, rasa ingin tahu pembaca. Bahwa suspense merupakan suatu hal yang amat penting didalam plot sebuah karya naratif.

\section{PEMBAHASAN}

Alur atau pemplotan adalah rangkaian cerita yang dimulai dengan cerita pembuka dan diakhiri dengan penutup cerita. Dalam rangkaian ceritra tersebut disusun seolah-olah merupakan kisah yang benarbenar hidup atau nyata. Suatu cerita fiksi dapat menarik pembaca bila pengarang mampu membawa atau menggiring pembaca untuk mengikuti alur cerita.

Sudjiman (1986:4) menyatakan bahwa alur adalah rangkaian peristiwa dan di jalin dengan seksama, yang menggerakkan jalan cerita melalui melalui rumitan kearah klimaks dan anti klimaks. Dengan kata lain, alur adalah jalinan peristiwa di dalam karya astara untuk 
mencapai efek tertentu dan pautan dapat diwujudkan oleh hubungan temporal (waktu) dan hubungan kausal (sebab akibat). Alur merupakan rentetan peristiwa yang menekankan pada hubungan akibat (Forster, 1970:87), sedangkan Chatman (1980:20) menyatakan bahwa alur adalah tata urutan pemunculan peristiwa-peristiwa dalam cerita. Karya sastra dapat membentuk kepribadian karna di dalamnya memuat amanat tentang moral, mengembangkan imajinasi dan kreativitas siswa.

\section{Hakikat Plot dan Pemplotan}

Beberapa pengertian menurut para ahli, antara lain: Stanton (1965:14), mengemukakan plot adalah cerita yang berisi urutan kejadian, namun tiap kejadian itu hanya di hubungkan secara sebab akibat, peristiwa yang satu di sebabkan atau menyebabkan terjadinya peristiwa lain.

Kenny (1966:14) mengemukakan plot sebagai peristiwa-peristiwa yang di tampilkan dalam cerita yang tidak bersifat sederhana, karena pengarang menyusun peristiwa-peristiwa itu berdasarkan kaitan sebab akibat. Plot menurut Foster (1970:93) adalah peristiwa-peristiwa cerita yang mempunyai penekanan pada adanya hubungan kausalitas.

\section{Pengertian Plot dan Pemplotan}

Hal-hal yang dikemukakan diatas kiranya dapat lebih memperjelas perbedaan anatara cerita dan plot sebagaimana yang dikemukakan Forster. Namun, sebenarnya kadar keeksplitisan hubungan kausalitas itulah, barangkali, yang membedakan. Jika masih merujuk pada teori Forster dalam kaitannya dengan teks fiksi maka akan mengandung plot. Hubungan antar peristiwa yang dikisahkan itu haruslah bersebab akibat, tidak hanya sekedar berurutan secara kronologis saja. Berbagai pengertian tentng plot yang dikemukakan orang pun, walau berbeda dalam hal perumusan, biasanya mempergunakan kata-kata (kunci) peristiwaperistiwa yang berhubungan sebab akibat.

Penampilan peristiwa demi peristiwa yang hanya mendasarkan diri pada urutan waktu saja belum merupakan plot. Agar menjadi sebuah plot, peristiwa-peristiwa itu haruslah diolah dan disiasati secara kreatif sehingga hasil pengolahan dan penyiasatannya itu sendiri merupakan suatu yang indah dan menarik. Kegiatan ini, dilihat dari sisi pengarang, merupakan kegiatan pengembangan plot atau dapat juga disebut dengan pemlotan (analog: alur dan pengaluran, tokoh dan penokohan). Kegiatan pemlotan meliputi kegiatan memilih peristiwa yang akan yang akan diceritakan dan kegiatan menata (baca: mengolah dan menyiasati) peristiwa-peristiwa itu ke dalam struktur linear teks fiksi.

Abrams (1999:224), yang juga menyetujui adanya perbedaan antara cerita dan plot, mengemukakan bahwa plot sebuah teks fiksi merupakan struktur peristiwaperistiwa, yaitu sebagiamana yang terlihat dalam pengurutan dan penyajian berbagai peristiwa tersebut untuk mencapai efek artistic dan emisional tertentu. Penyajian peristiwa-peristiwa itu, atau secara lebih khusus aksi "action", tokoh baik yang verbal maupun nonverbal dalam sebuah teks bersifat linear, namun antara peristiwa yang dikemukakan sebelumnya dan sesudahnya belum tentu berhubungan langsung secara logis- bersebab akibat. Pertimbangan dan pengolahan struktur cerita, penataan peristiwa-peristiwa, selalu dalam kaitannya pencarian efek tertentu yang ingin di capai.

Jika kita membutuhkan defenisi tentang plot, plot tampaknya dapat dipahami sebagai berbagai peritiwa yang diseleksi dan 
diurutkan berdasarkan hubungan sebab akibat untuk mencapai efek tertentu dan sekaligus membangkitkan suspense dan surprise pada pembaca.

\section{Plot: Misterius Intelektual}

Plot sebuah cerita fiksi, sebagaimana dikatakan Forster, memiliki sifat misterius dan intelektual. Plot menampilkan kejadiankejadian yang mengandung konflik yang mampu menarik atau bahkan mengharukan atau mencekam pembaca. Hal itu mendorong pembaca untuk mengetahui kejaidan-kejadian berikutnya. Namun, hal itu tidak akan dikemukakan begitu saja sekaligus cepat oleh pengarang, melainkan mungkin disiasati dengan hanya menuturkan sedikit demi sedikit, sengaja "memisahkan" peristiwa-peristiwa yang sebenarnya berhubungan logis langsung, atau menunda (baca: menyembunyikannya) pembenaran sesuatu yang menjadi kunci permasalahan. Dengan cara yang demikian, biasanya hal itu justru akan lebih mendorong pembaca untuk mengetahui kelanjutan kejadian yang diharapkan. Keadaan yang demikian inilah yang oleh Forster disebut sebagai sifat misteriusnya plot.

Sifat misteriusnya plot tersebut tampaknya tidak berbeda haknya, atau kaitannya dengan pencapaian suspense, rasa ingin tahu pembaca. Forster juga mengakui bahwa unsur suspense merupakan suatu hal yang amat penting dalam plo sebuah karya naratif. Suspense membangkitkan rasa penasaran dan tidak sabat untuk segera mengetahui cerita selanjutnya. Unsur inilah antara lain yang menjadi pendorong pembaca untuk mau menyelesaikan novel yang dibacanya. Sebenarnya dalam kegiatan sehari-hari kita pun akan selalu berhadapan dengan hal-hal yang bersifat misterius, tidak jelas, dan bahkan absur. Artinya, hal-hal yang menarik dan mencekam perhatian kita tentang bagaimana kelanjutan peristiwa, kasus, situasi, atau masalah tidak dapat begitu saja diperoleh karena semuanya masih dalam proses.

Untuk mengetahui penyelesaian masalahnya, kita harus dengan sabar menunggu dalam waktu yang tidak menentu, bahkan tidak jarang kita menjadi melupakannya. Keadaan itu sebenarnya lebih misterius dari pada mksteri yang di tampilkan dalam cerita novel itu dibaca, kemisteriusan itu akan terpecahkan.

Misalnya, ada peristiwa perampokan pada sebuah took di siang hari bolong. Perbuatan yang tergolong berani itu tentu akan menarik perhatian banyak orang. Maka, orang akan segera mengajukan pertanyaan: siapa pelakunya, berapa kerugian, sudahkan polisi menyelidiki perampok itu, sudahkan mereka tertangkap, siapa saja yang berdiri dibelakang peritiwa itu, kapan mereka diadili, berapa lama mereka harus mendekam dipenjara, dan sebagainya. Tentu saja, pertanyaanpertanyaan yang memberondong itu tidak mudah di jawab dan untuk memperoleh jawabannya harus menunggu waktu selama entah berapa lama, atau bahkan mungkin tidak pernah kesampaian.

Oleh karena plot bersifat misterius, untuk memahamunya diperlukan kemampuan intelektual. Tanpa disertai adanya daya intelektual. Kata Foster, tiak mungkin orang dapat memahami plot cerita dengan baik. Hubungan antarperistiwa, kasus, atau berbagai persoalan yang diungkapkan dalam sebuah karya, belum tentu ditunjukkan secara eksplisit dan langsung oleh pengarang. Menghadapi struktur narasi yang demikian pembaca diharpakan mampu menemukan sendiri. 
Pemahaman terhadap plot, dengan demikian, memerlukan daya kritis, kepekaan pikiran dan perasaan, serta sikap dan tanggapan yang serius. Usaha pemahaman tersebut ada kaitannya dengan mempertimbangkan dan atau menlai struktur plot sebuah karya.

\section{Peristiwa, Konflik, dan Klimaks}

Peristiwa dapat diartikan sebagai peralihan dari suatu keadaan ke keadaan yang lain (Lukxemburg, 1992:150). Peristiwa dibagi menajdi tiga tergantung dari mana ia di lihat.

Peristiwa fungsional adalah peristiwa-peristiwa yang menentukan dan atau mempengaruhi perkembangan plot. Urutan-urutan peristiwa fungsional merupakan inti sebuah cerita karya fiksi yang bersangkutan. Peristiwa kaitan adalah peristiwa-peristiwa yang berfungsi mengaitkan peristiwa-peristiwa penting dalam pengurutan penyajian cerita.

Peristiwa acuan adalah peristiwa yang tidak secara langsung berpengaruh dan berhubungan dengan perkembangan plot, melainkan mengacu pada aunsur-unsur lain, misalnya berhubungan dengan masalah perwatakan atau suasana yang melingkupi batin tokoh.

Dalam penulisan ini, dengan tujuan sekaligus untuk menyederhanakan masalah, action dan event di rangkum menjadi satu istilah: peristiwa atau kejadian. Perbedaan anatara action dan event hanya menjebak kita dalam kesulitan dan kecermatan.

Peristiwa dapat diartikan sebagai peralihan dari suatu keadaan ke keadaan yang lain (Luxemburg dkk, 1992:150), peralihan dari satu aktivitas ke akvitas yang lain. Berdasarkan pengertian lain, kita dapat membedakan kalimat-kalimat tertentu yang menampilkan peristiwa dengan yang tidak. Misalnya antara kalimat-kalimat yang mendeskripsikan tindakan tokoh dan yang mendiskripsikan ciri-ciri fisik tokoh. Peristiwa-peristiwa yang ditampilkan dalam sebuah cerita fiksi pastilah banyak sekali, namun, tidak semua peristiwa tersebut berfungsi sebagai pendukung plot. Itulah sebabnya, untuk menentukan peristiwaperistiwa fungsional dengan yang bukan diperlukan penyeleksian atau tepatnya: analisis peristiwa.

Melalui analisi peristiwa akan dpat diketahui peristiwa mana saja yang dapat di klasifikasikan kedalam jenis tersebut. Selain itu, jumlah dan perbandingan ketiga jenis peristiwa itu, sekaligus apakah ia berwujud peristiwa fisik atau batin. Dalam sebuah cerita fiksi juga dapat ditemukan. Jika peristiwa fungsional mendominasi, berjumlah jauh melebihi jumlah peristiwa kaitan dan acuan. Plot novel bersangkutan cenderung berplot padat. Melalui analisis peristiwa tersebut juga dapat diketahui bagaimaan variasi penyajian peristiwa itu, dominasi dan wujud tindakan secara visual.

Konflik yang notabene adalah kejadian yang tergolong penting, merupakan esensial dalam perkembangan plot. Konflik menyarang pada pegertian sesuatu yang bersifat tidak menyenangkan yang terjadi dan atau di alamai oleh tokoh-tokoh cerita. Konflik adalah sesuatu yang dramatik, mengacu pada pertarungan anatara dua kekuatan yang seimbang dan menyiratkan adanya aksi dan aksi balasan (Wellek \& Warren, 1989:285). Peristiwa dan konflik biasanya berkaitan erat, dapat saling menyebabkan terjdinya satu dengan yang lain, bahkan konflik pun hakikatnya merupakan peristiwa. Bentuk peristiwa dalam sebuah cerita, dapat berupa peristiwa fisik ataupun batin. Konflik internal, yaitu: konflik fisik adalah sesuatu yang terjadi dengan melibatkan aktivitas, ada interaksi anatara seorang tokoh ceraita dengan sesuatu yang diluar dirinya. Konflik batin adalah sesuatu yang terjadi dalam batin, hati, seseorang tokoh.

Konflik eksternal, yaitu: konflik fisik/elemental adalah konflik yang disebabkan adanya benturan antara tokoh dengan lingkungan alam. Konflik sosial adalah konflik yang disebabkan adanya kontak sosial antaramanusia atau masalah 
yang muncul akibat adanya hubungan antar manusia.

Klimaks menurut Stanton (1965:16), adalah saat konflik telah mencapai tingkat intensitas tertinggi, dan saat (hal) itu merupakan sesuatu yang tidak dapat dihindari kejadiannya. Dalamsebuah karya fiksi kita temui dan rasakan, ternyata sulit menentukan klimaks. Orang bisa berbeda pendapat dalam menentukan klimaks.

\section{Kaidah Pemplotan}

Pengarang dalam menciptakan larya sastra mencapai kebebasan, baik itu dalam menetukan ceritanya. Begitu juga pengarang memilki kebebasan dalam menentukan struktur novel pembangunan karya sastranya. Baik itu peristiwa, konflik, latar, tokoh dan lain-lainnya merupakan hak progratif si pengarang. Nugriyantoro (2013:187) mengemukakan bahwa novel merupakan sebuah karya yang bersifat imajinatif dan kreatif tersebutlah yang memberikan kebebasan pada pengarang dalam menentukan karya sastra (novel) yang akan dibuatnya. Dalam hal pemplotan, pengarang juga bebas dalam mengembangkan plot menurut kratifitas sip pengarang. Namun, menurut Nugriyanto (2013:188) menayatakan bahwa kebebasan pengarang dalm mengembangkan segala aspek strutur karya sastra (dalam hal ini pemplotan) bukannya tanpa aturan, ada semacam aturan, ketentuan konvensi, atau kaidah dalam mengembangkan plot (the law of the plot) yang perlu dipertimbangkan , namun aturan itu bukan suatu harga mati untuk para pengarang. Menurut Kenny ( dalam Nurgiyantoro, (2013:188), kaidahkaidah pemplotan itu adalah palausibilitas ( palaungsibillity), unsur kejutan, (surprise), rasa ingin tahu (suspense), dan kepaduan (unity).
Palausibilitas

(plausibillity)

menunjukkan pada pengertian suatu hal yang dapat di percaya dengan sesuai dengan logika cerita, artinya sebuah plot cerita haruslah dapat dipercaya oleh pembaca (plausibel) (Nurgiantoro, 2013:188) plausibilitas dapat di kaitkan dengan Sesuatu yang ada dan terjadi di dunia nyata.

Unsur kejutan (suprise) sebuah cerita yang baik pastilah memiliki kadar surprise yang tinggi dan terjaga. Atau lebih tepatnya mampu membangkitkan sispense, membangkiykan rasa ingin tahu pembaca.

Rasa ingin tahu (suspense) penampilan peristiwa dalam sebuah cerita biasanya sudah di prediksi akhir ceritanya, atau ending dari sebuah cerita sudah dapat di ketahui oleh pembaca.

Kepaduan (unity) kesatu paduan merujuk pada pengertian bahwa berbagai unsur yang di tampilkan, khususnya peristiwa-peristiwa dan konflik, serta seluruh pengalamn hidup yang hendak di komunikasikan, memiliki terkaitan satu sama lain.

\section{Kaidah Pemplotan}

Nurgiyantoro

(2005:201-210)

membagi tahap pemplotan secara teoritaskronologis menjadi tahap plot: awal-tengahakhir, tahap plot: rincian lain.

Tahap plot: awal-tengah-akhir. Tahap awal atau tahap perkenalan, pada umunya berisi sejumlah informasipenting yang berkaitan dengan berbagai hal yang akan di kisahkan pada tahap-tahap berikut. Misalkan, penunjukan dan pengenalan latar, seperti nama-nama, tempat, suasana, alam, waktu kejadian, dan lain-lain yang garis besarnya berupa deskrifi setting. Fungsi pokok tahap awal (pembukaan) sebuah cerita adalah untuk memberikan informasi 
dan penjelasan seperlunya khususnya yang berkaitan dengan peralatan dan penokohon.

Tahap tengah atau tahap pertingkaian menampilkan pertentangan atau konflik, bagian tengah cerita merupakan bagian terpanjang dan terpenting dari sebuah cerita fiksi. Pada bagian ini cerita di sajikan: tokoh-tokoh memainkan peran, peristiwaperistiwa fungsional dikisahkan, konflik berkembang semakin meruncing, menegakan dan mencapai klimaks, dan pada umumnya tema pokok, makna pokok ceruta di ungkapkan.

Tahap akhir atau tahap pelaraian, menampilkan adegan tertentu sebagai akibat klimaks. Bagian ini berisi bagaimana kesudahan cerita. Menurut Aristoteles (dalam Nugriyantoro, 2005:205), penyelesaian cerita dibedakan kedalam dua macam kemunkinan, kebahagiaan (happy end) dan kesedihan (sad end).

Tahap plot: rincian lain. Tahap plot rincian lain terdiri dari beberapa tahap, yaitu tahap situasion, tahap penyisuation, berisi pelukisan dan pengenalan situasi latar atau tokoh-tokoh cerita. Tahap generating circumstances, tahap pemunculan konflik, masalah-masalah dan peristiwa-peristiwa yang menyulut terjadinya konflik mulai di munculkan, tahap rising action, tahap peningkatan konflik, konflik yang telah dimunculkan pada tahap sebelumnya semakin berkembang dan dikembangkan kadar intensitasnya, tahap climax, tahap klimaks, komflik dan pertentanganpertentangan yang terjadi, yang dilakui atau ditimpalkan kepada para tokoh cerita mencapai titik intensitas puncak, tahap denouement, tahap penyelesaian, konflik yang telah mencapai klimaks diberi penyelesaian, ketegangan dikendorkan.

\section{Perbedaan Alur (Plot)}

Nurgiyanto membedakan pembagian plot berdasarkan, kreteria urutan waktu, kreteria jumlah, kreteria kepadatan dan kreteria isi (2005:212).

Plot berdasarkan kriteria urutan waktu. Plot berdasarkan kriteria urutan waktu terbagi menjadi, pertama plot lurus/progresif, jika peristiwa-peristiwayang di kisahkan bersifat kronologis atau peristiwa-peristiwa yang dimunculkan secara urut (bagian awal, tengah, dan akhir). Kedua, plot sorot balik/ flash back, tidak bersifat kronologis, cerita tidak dimulai dari tahp awal mungkin dari tahap tengah atau tahap akhir. Ketiga alur ca,puran, alur campuran merupakan campuran dari semau alur yang ada (plot lurus, plot sorot balik) dalam sebuah novel.

\section{Plot berdasarkan kriteria jumlah.}

Berdasrkan kriteria jumlahnya plot terbagi menjadi, pertama plot tunggal, plot yang mengembangkan sebuah cerita. Cerita pada umumnya yang hanya mengikuti perjalananhidup tokoh lengkap dengan permasalahan dan konflik yang dialaminya. Kedua plot syb-subplot (plot paralel), memiliki lebih dari satu alur cerita. Sturuktu plot yang demikian dalam sebuah karya barangkali berupa adanya sebuah plot utama (main plot) dan plot-plot tambahan (subsubplot).

Perkembangan plot berdasarkan kriteria kepadatan. Pertama plot padat, disamping cerita disajikan secara cepat, peristiwa fungsional terjadi susul-menyusul dengan cepat, hubungan antar peristiwa juga terjalin secara cepat. Berharap dengan novel yang demikian, pembaca seolah-olah selalu di paksa untuk terus menerus mengikutinya. Antar peristiwa satu dengan peristiwa yang lain yang sekedar fungsional tinggi tidak 
dapat di pisahkan atau dihilangkan. Setiap peristiwa yang ditampilkan terasa penting dan berperan menetukan dalam rangkaian cerita. Namun, yang perlu di catat adalah bahwa kadar kepadatan antar tiap bab,episode, atau bagian novel biasanya tidak sama. Novel yang berplot padat sebagai konsekuensinya ceritanya yang padat dan cepat, akan kurang menampilkan adegan-adegan penyituasian yang berkepanjangan.

Kedua plot longgar, pergantian antara peristiwa penting berlangsung lambat di samping hungan antar peristiwa tersebut juga tidaklah erat benar. Bahkan, antara peristiwa penting yang satu dengan yang lain sering di sisipkan oleh berbagai peristiwa "tambahan" atau berbagai pelukisan tertentu seperti penyituasian latar dan suasana yang kesemuannya itu dapat memperlambat ketegangan cerita.

Plot berdasarkan kriteria isi. Friedman (dalam Nugriyantoro, 2005:222), membedakn jenis plot ini kedalam tiga golongan besar, yaitu plot peruntungan (plot of fortune), plot tokohan (plot of character), plot pemikiran (plot pf thought). Plot peruntungan (plot of fortune), plot ini berhubungan dengan tokoh (utama) cerita pada sebuah fiksi. Plot peruntungan dibedakn menjadi : plot gerak, plot sedih, plot tragis, plot penghukkuman, plot sentimental, dan plot kekaguman.

Plot tokohan, menunjukan pada adanya sifat pementingan tokoh, ada tokoh yang menjadi perhatian. Plot tokohan lebih banyak menyoroti keadaan tokoh dari pada kejadian-kejadian peristiwa yang ada atau berurusan dengan pemlotan. Plot penokohan dibedakan menjadi empat yaitu : plot pendewasaan (maturing plot), plot pembentukan (reform plot), plot pengujian (testing plot), plot kemunduran (degeneration plot).

Plot pemikiran, mengungkapkan sesuatu yang menjaid bahan pemikiran, keinginan, perasaan, berbagai macam obsens, dan lain-lain yang menjadi masalah hidup dan kehidupan manusia. Friedman membedakan plot pemikiran kedalam, plot pendidikan (education plot), plot pembukaan rahasia (revelation plot), plot afektifm(affective plot), dan plot kekecewaan (didillusionment)

\section{PENUTUP}

Salah satu elemen terpenting dalam membentuk sebuah karya sastra adalah plot cerita. Dalam analisi cerita, plot sering disebut dengan istilah alur. Dalam pengertiannya yang paling umum, plot atau alur sering diartikan sebagai keseluruhan rangkaian peristiwa yang terdapat dalam cerita. Seorang pengarang dalam menggerakkan cerita tentu dengan jalan mengalirkan kisah itu melalui peristiwa demi peristiwa, sehingga jalan cerita dapat dimengerti oleh pembacanya. Jalan cerita tersebut layaknya disebut alur. Alur biasanya terbatas pada peristiwa-peristiwa yang berhubungkan secara kausal. Peristiwa kaausal yaitu peristiwa yang menyebabkan atau menjadi dampak dari berbagai peristiwa lainya. Peristiwa-peristiwa yang ada dalam sebuah cerita rekaan saling berkaitan untuk membentuk suatu jalan cerita yang selaras. Alur di dalam sebuah cerita membangun sebuah peristiwaperistiwa dengan rurutan tertentu.

\section{DAFTAR PUSTAKA}

Desierawati. 2014. Alur dan Pengaluran. wordpress.com/2014/12/29/makalah-alur-danpengaluranhttp://gugusansastrashella.Blogspot.Com/2016/12/Makassar-plot-danpemplotan.htm?m=1./ Diakses tanggal 1 desember 2016 
Mansyur, Umar. 2016. Pemanfaatan Nilai kejujuran dalam Cerpen sebagai Bahan Ajar Berbasis Pendidikan Karakter. In Mengais Karakter dalam Sastra: HISKI Makassar (pp. 330-339). https://doi.org/10.17605/OSF.IO/Z4T3Y

Mansyur, Umar. 2018. Kiat dan Teknik Penulisan Skripsi bagi Mahasiswa. INA-Rxiv. https://doi.org/10.31227/osf.io/juds7

Muliadi. 2017. Buku Ajar Telaah Prosa. Makassar: De La Macca.

Nurgiyanto, Burhan. 2015. Teori pengajaran fiksi. Yogyakarta: Gadjah Mada University Press

Stanton. Tentang bahasa dan sastra.blogspot.com/2017/01/alur-plot-201226-alur.html?m=1. Diakses pada tanggal 24 januari 2017 